\title{
Terminal Efficiency in Educational Programs of Economic - Administrative Sciences of the Technological Institute of Campeche
}

\section{La Eficiencia Terminal en los Programas Educativos de Ciencias Económico - Administrativas del Instituto Tecnológico de Campeche}

LEGORRETA-BARRANCOS, Leydi Elena ${ }^{1} \dagger^{*}$, ORTEGA-RODRÍGUEZ, Ana Luisa ${ }^{1}$, SUÁREZAMÉNDOLA, Rosario De Fátima ${ }^{2}$ and GARCÍA-PÉREZ, Sergio Francisco ${ }^{1}$

Instituto Tecnológico de Campeche - Tecnológico Nacional de México, ${ }^{1}$ Department of Economic and Administrative Sciences, ${ }^{2}$ Department of Computer Systems

ID $1^{\text {st }}$ Author: Leydi Elena, Legorreta-Barrancos / ORC ID: 0000-0002-8918-4226, CVU CONACYT ID: 725501

ID $1^{\text {st }}$ Coauthor: Ana Luisa, Ortega-Rodríguez / ORC ID: 0000-0002-0134-2008, CVU CONACYT ID: 228237

ID $2^{\text {nd }}$ Coauthor: Rosario De Fátima, Suárez-Améndola / ORC ID: 0000-0003-1600-7875, Researcher ID Thomson: Q3394-2017, CVU CONACYT ID: 279998

ID $3^{\text {rd }}$ Coauthor: Sergio Francisco, García-Pérez / ORC ID: 0000-0002-4538-068X, CVU CONACYT ID:997074

DOI: $10.35429 /$ EJC.2019.9.5.8.14

Received September 10, 2019; Accepted December 30, 2019

\begin{abstract}
The Higher Education System (HES) undoubtedly represents an opportunity for the generation of high performance learning communities, innovation and technological development; being able to modify social structures through different areas of knowledge and respond to the challenges posed by the National Technological Institute of Mexico (TecNM) such as: coverage, quality and relevance for regional development and the advances of the new Educational Model. In the present paper, the terminal efficiency of educational programs in the area of Economics - Administrative Sciences of the Technological Institute of Campeche (ITC) is analyzed as an attempt to build indicators, to know the efficiency in the application of school resources in training of graduates and to be able to affirm the strategic value of knowledge, attending its demands and competing successfully in the labor market, which is considered as the fundamental axis of the social, cultural, economic and political development of nations.
\end{abstract}

Technological Higher Education, Terminal Efficiency, Plans and Educational Programs.

\begin{abstract}
Resumen
Las Instituciones de Educación Superior (IES), indudablemente representa una oportunidad para la generación de comunidades de aprendizaje de alto desempeño, la innovación y el desarrollo tecnológico; capaces de modificar las estructuras sociales a través de las distintas áreas del conocimiento y responder así, a los desafíos planteados por el del Tecnológico Nacional de México (TecNM) como son: cobertura, calidad y pertinencia para el desarrollo regional y los avances del nuevo Modelo Educativo. En el presente estudio se analiza la eficiencia terminal de los programas educativos del área de Ciencias Económico - Administrativas del Instituto Tecnológico de Campeche (ITC), como un intento de construir indicadores, para conocer la eficiencia en la aplicación de los recursos escolares en la formación académica de los egresados y poder afirmar el valor estratégico del conocimiento, atendiendo las demandas del mismo y competir con éxito en el mercado profesional, al considerarse éste, el eje fundamental del desarrollo social, cultural, económico y político de las naciones.
\end{abstract}

Educación Superior Tecnológica, Eficiencia Terminal, Planes y programas Educativos.

Citation: LEGORRETA-BARRANCOS, Leydi Elena, ORTEGA-RODRÍGUEZ, Ana Luisa, SUÁREZ-AMÉNDOLA, Rosario De Fátima and GARCÍA-PÉREZ, Sergio Francisco Terminal Efficiency in Educational Programs of Economic Administrative Sciences of the Technological Institute of Campeche. Journal-Republic of Colombia. 2019. 5-8: 8-14

\footnotetext{
* Correspondence to Author (email: leydi.legorreta@itcampeche.edu.mx)

$\dagger$ Researcher contributing as first author.
} 


\section{Introduction}

Improving the terminal efficiency indicator has always been a topic of interest to HEIs because it is a useful way to measure the effectiveness and efficiency of their educational process and as a reference for the analysis of students' school behavior. Sánchez G., (2000) asserts that there are studies which demonstrate that terminal efficiency remains a challenge to overcome related to the problem of non-graduation.

According to the National Association of Universities and Institutions of Higher Education (ANUIES, for its acronym in Spanish) the national average terminal efficiency considered for graduation is 54 percent, being the public HEI where this phenomenon is most frequent, against 66 percent for private HEI students (Hernández, 2015).

The Area of Economic-Administrative Sciences of the Technological Institute of Campeche (ITC) has two majors: Engineering in Administration and Engineering in Business Management. Although there are semiannual records to monitor the progress of students, the possible problems they face throughout their educational programs are unknown and therefore the behavior of terminal efficiency. This study aims to identify the behavior of the performance indicators of both educational programs and estimate the 2010-2014 generation terminal efficiency of the curricula by competences assigned to the area, which will allow rethinking student retention strategies.

\section{Technological Higher Education}

The public Technological Higher Education has the purpose of providing students with the basic skills and abilities to participate in the labor market. But its most important objective is that students learn to learn and develop a cooperative and professional spirit which, by putting into practice, improves their attributes as persons and professionals.

For this, one of its essential strategies is the Model of Technological Higher Education, focused on the scientific, technological and humanistic training of the students, and their close relation with the productive sector of goods and services, as well as centers of scientific and technological research, in order to favor dual education, updated and ongoing training.
On July 23, 2014, with the higher education bill, the National Technological Institute of Mexico (TecNM) was created as a decentralized body of the Ministry of Public Education (DOF. 2014, 07 23). Without a doubt, it represented a significant milestone for higher education in the country, which after 70 years has managed to become the largest and most important system in Latin America, since it trains 42 percent of engineers across the country.

Evidently, to strengthen institutional work and achieve the national goal of forging a country with Quality Education, the TecNM (2014) presents its Institutional Program for Innovation and Development (PIID, for its acronym in Spanish) 2013-2018 to ratify the commitment to achieve better results, by aligning the objectives, strategies, lines of action and indicators contemplated in said program.

The above is a result of the national diagnosis carried out during the 2012-2013 school year; Likewise, it is determined that according to the demand, there is a completion rate of 66.7 percent, the graduation index is 72.8 percent, and a terminal efficiency of 54.33 percent; so the challenges faced are:

Increasing the terminal efficiency
indices,
Increasing undergraduate and
postgraduate enrollment
Promoting at a national level non-
presence-based -at a distance- and mixed
education services;

Which necessarily supports the updating of the Handbook of Academic-Administrative Guidelines (TecNM, 2015) as a joint effort, reaffirming the commitment to ensure quality Technological Education for the training process at a Bachelor level.

\section{Terminal Efficiency}

In the educational context, terminal efficiency (TE) is a very important indicator of effectiveness and refers to the degree to which students entering the education system advance along the educational level in the expected time. In quantitative terms, the Ministry of Public Education (SEP, for its acronym in Spanish) defines it as "the proportion between the number of students entering and those who graduate from the same generation. 
Considering the year of admission and the year of graduation according to the duration of the study plan" (SEP, 2105 in Domínguez, D.; Sandoval, M.; Cruz, F.; and Pulido, A. 2014); as Cuellar and Bolívar (2006) state, it is the number of students who complete an educational level within the established or regular time in the program, that is, the percentage of students that timely conclude an educational level according to the number of years planned.

$\mathrm{TE}=\frac{\text { Egn }}{\mathrm{NI} 1(\mathrm{n}-\mathrm{d})} \times 100$

\section{$\mathrm{TE}_{\mathrm{n}}=$ Terminal Efficiency}

$\mathrm{Eg}_{\mathrm{n}}=$ Graduates of the educational level

NI1 = New enrollment to first grade of the educational level registered d-1 school cycles ago.

$\mathrm{n}=$ Duration of the educational level

$\mathrm{d}=$ School cycle

According to Blanco and Rangel (2000), the terminal efficiency of a program is defined as the ratio resulting from dividing the number of students belonging to a given cohort who graduated from said program at a certain time, between the students who entered that program in a previous moment. To calculate this index, it is not enough to have the annual enrollment and graduation data, but it is necessary to effectively track the trajectory of each group of students who share the characteristic of having started certain studies at the same time, following them individually to know if they continue studying in the same program, if they changed to another, if they temporarily interrupted their bachelor but intend to continue it, if they have abandoned it permanently, if they finished it, and inn how much time they completed it.

With the longitudinal data, for a given enrolled generation, the TE is simply the percentage of those who completed their studies (what ANUIES calls "completion efficiency") or graduated ("graduation efficiency"); TecNM (2014) represents it as the percentage of students who have a bachelor's degree in the school year $n$ with respect to the number of students who began the same level five years before, represented as follows:

PET $=($ Total students graduated/Total students in the generation cohort) $* 100$

It also considers Completion Efficiency:
$\mathrm{CE}=$ (Total of students who completed the program in the school year $n /$ total of new students 5 years before) $* 100$

In this sense, the results of the calculation of terminal efficiency are a manifestation of the efficiency of the education system, because if the result is low, it reflects the institution's deficiencies, such as educational policies, curricula, degree options, among others. In this regard, the ITC, through its massive graduation strategy, has managed to increase terminal efficiency in all its educational programs.

The TecNM (2015) has incorporated various graduation options according to the new educational model in order to improve terminal efficiency indices. In this way, it recognizes integral graduation as the validation of the competences (knowledge, skills and attitudes) that the student acquired and developed during his professional training, such as:

- Integral Graduation Projects: Professional Residence, Research and/or Technological Development Project, Integrative Project, Productive Project, Technological Innovation Project, Entrepreneurship Project, Dual Education Integral Project, Stays or Thesis.

- The Testimony of Satisfactory or Outstanding Performance in the General Examination of Bachelor Completion (EGEL, for its acronym in Spanish) of the National Center of Evaluation for Higher Education, A. C. (CENEVAL, for its acronym in Spanish.)

It can be said that the system provides a wide range of possibilities for the student to obtain a professional degree, which gives them greater opportunities to join the labor market, which improves the graduation rates, qualification and terminal efficiency.

In the case at hand, two variants of the notion of terminal efficiency are distinguished: completion and graduation, and the graduate is defined as the student who has approved all the credits or elements that make up the curriculum, regardless of any institutional norm. 


\section{Study plans and programs}

The term study plan is derived from the Latin expression: ratio studiorum, which means rational organization of studies (Furlán, 1998: 96.) Casarini, Glazman and Ibarrola (1999: 8) state that: "Study plans and programs are guiding documents that prescribe the purposes, contents and actions to be carried out by the teacher and the students, aimed at developing a curriculum." Therefore, all formal education implies the existence of study plans and programs, and, of course, an educational institution in charge of its application, which requires the establishment of well-defined procedures for facilitating activities, as well as control, registration and accreditation (Bergeron, 1993 in Cuellar and Bolívar, 2006).

The TecNM (2014) defines a study plan as the synthetic, schematized and structured reference of the subjects or other types of learning units, including an evaluation proposal to maintain its relevance and validity. It can be said that it is the formal curricular design that is applied to certain teachings and its graphic representation is the curricular map, where the organization and distribution of the subjects, areas or modules is comprehensively visualized.

It allows establishing vertical relationship, that is, to analyze what relations exist between the subjects of each school semester, the links that can be established between them, how an integration or retrieval of contents can be promoted to help students establish interaction nuclei; as well as horizontal relationship, which refers to the link between subjects of all semesters, reflecting criteria of continuity, sequence and integration of the contents.

The study programs refer to the synthesized description of the contents of the subjects or learning topics, ordered by sequences or by areas related to the indispensable didactic and bibliographic resources, with which the teaching-learning process will be regulated, which needs to be evaluated according to the criteria demanded by the educational quality policy (TecNM, 2015). The structured articulation of the subject, activities and learning experiences, based on predetermined criteria and competences, which provide knowledge, develop skills and promote values and attitudes in the student are crucial.
Given the above, the question arises: When should the student be considered to have completed his or her training?

In principle, and if only the substantive aspects are considered, this occurs when the students have adequately finished all the academic, theoretical and practical activities required by the program, that is, when they have completed it.

In the context of the ITC, the educational programs of Administration Engineering and Engineering in Business Management opened in the period August-December of the year 2009 and 2010 respectively, with a duration of nine semesters. According to the regulations, students have a maximum period of twelve semesters to conclude, which emphasizes the curricular flexibility, giving the students freedom to choose their academic load each school year within determined ranges.

In the case of higher education, it is said that this measurement has no way of knowing the degree of success ("terminal efficiency") of the new generation and constitutes a very weak approach to the phenomenon to be measured. Indeed, in a given year, individuals enrolled in different years may graduate, in particular when there are no maximum deadlines for graduating (as is the case). The existence of a term only reduces variation, but does not improve the estimate since it only impacts student retention.

\section{Methodology}

The research was quantitative and of descriptive scope, since it allows to know the reality of a phenomenon and the events that surround it through its manifestations (Hernández, Fernández and Baptista, 2014 p. 4); we used a non-experimental exploratory research design, which "is done without deliberately manipulating the dependent variables, is based on variables that already occurred or happened without the direct intervention of the researcher" (Hernández et al., 1994: 204.) Since this subject has not been previously addressed or has been little studied, as is the case of the behavior of the generational efficiency 2010-2014 of the curricula in the area of EconomicAdministrative Sciences of the ITC, we implemented the following actions: 
- Obtaining generational data in the Integral Information System (SII, for its acronym in Spanish).

Identification of performance indicators of educational programs in the area of Economic-Administrative Sciences.

Analysis and interpretation of the generational historical records.

Estimation of the behavior of generational TE 2010 - 2014.

\section{Results}

Digitally there are aggregated data from complete generations as a work of longitudinal monitoring of students in real cohorts, which yields a history of relevant data for interpretation (See Table 1 and 2).

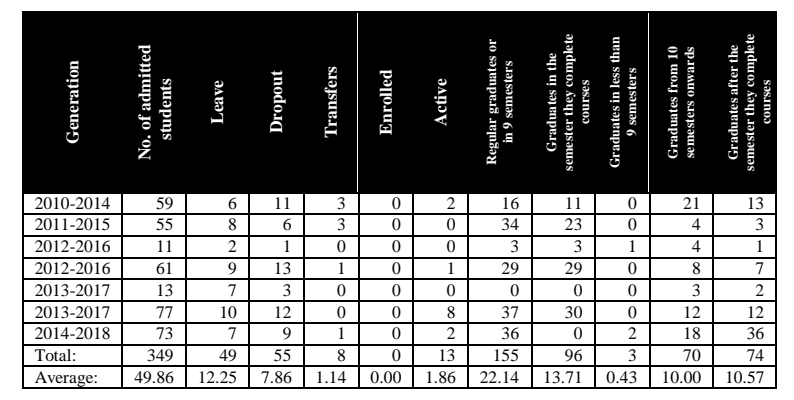

Table 1 Generational data of Administration Engineering Source: Prepared by the authors, 2019

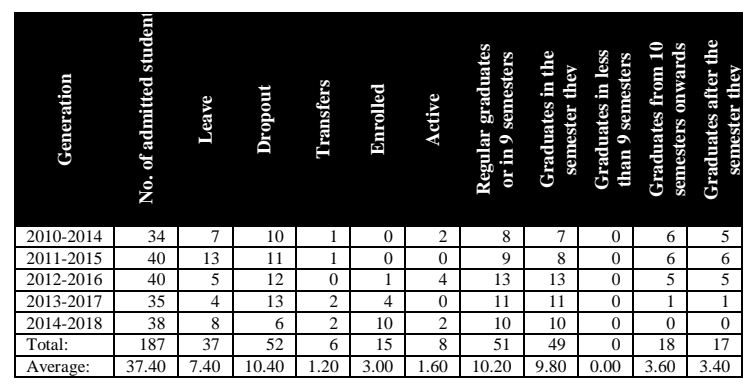

Table 2 Generational data of Engineering in Business Management

Source: Prepared by the authors, 2019

Currently, Mexico has the lowest ratio among the countries of the Organization for Economic Co-operation and Development (OECD, 2019) of adults between 25-64 years of age with a degree in higher education (17\%); a number far below the OECD average (37\%).

We found averages of $24 \%$ for $\mathrm{AE}$ and $13 \%$ for EBM, which brings us to a general average of the area $(18.5 \%)$, confirming the place that the country occupies.
As it can be seen, there is greater demand in AE, even though there are students who know how to take advantage of the flexibility of the system and conclude their studies before nine semesters, without knowing the time of their graduation.

Likewise, we can calculate indicators to see the efficiency of the educational process of the Area of Economic and Administrative Sciences, determining the following in their educational plans (See table 3).

\begin{tabular}{|c|c|c|}
\multirow{2}{*}{ Generation } & \multicolumn{2}{c|}{ CEI } \\
& AE & EBM \\
\hline $2010-2014$ & $27 \%$ & $23 \%$ \\
\hline $2011-2015$ & $62 \%$ & $22 \%$ \\
\hline $2012-2016$ & $27 \%$ & $32 \%$ \\
\hline $2012-2016$ & $47 \%$ & $0 \%$ \\
\hline $2013-2017$ & 0 & $31 \%$ \\
\hline $2013-2017$ & $48 \%$ & $0 \%$ \\
\hline $2014-2018$ & $49 \%$ & $26 \%$ \\
\hline Promedio: & $37 \%$ & $19 \%$ \\
\hline
\end{tabular}

Table 3 Comparison of the Completion Efficiency Index Source: Prepared by the authors, 2019

The average number of students in $\mathrm{AE}$, for the year 2019, corresponds to 37 percent that confirm its demand. The administration area is one of the two most frequent fields of study nationwide, with 35.1 percent, so it is important to maintain the accreditation granted by CACECA, valid from November 28, 2017 to 2022. However, it is observed that terminal efficiency at a general level is low in relation to the number of students enrolling; The National Education Statistics Information System (SNIEE, for its acronym in Spanish) of the SEP (2015) establishes that the efficiency index of federal HEIs is 62.75 percent, so it would be necessary to analyze failing rates and design attention and follow-up actions, because apparently the impact of the tutoring program has not been sufficient enough to meet the needs of the students who fail (see Table 4).

\begin{tabular}{|c|r|r|}
\multicolumn{2}{r}{ Generation } & \multicolumn{2}{c}{ IT } \\
\cline { 1 - 2 } & AE & EBM \\
\hline $2010-2014$ & $19 \%$ & $21 \%$ \\
\hline $2011-2015$ & $42 \%$ & $20 \%$ \\
\hline $2012-2016$ & $27 \%$ & $32 \%$ \\
\hline $2012-2016$ & $45 \%$ & 0 \\
\hline $2013-2017$ & 0 & $31 \%$ \\
\hline $2013-2017$ & $38 \%$ & 0 \\
\hline $2014-2018$ & $49 \%$ & $26 \%$ \\
\hline Average: & $36.6 \%$ & $31 \%$ \\
\hline
\end{tabular}

Table 4 Comparison of the Graduation Efficiency Index Source: Prepared by the authors, 2019 
For the completion/graduation relationship, both engineering degrees have indexes below the national average, that is, 54 percent (OECD, 2019). It should be noted that after the generation that graduated in 2014, the "massive graduation" strategy of Professional Residence was adopted, generating a slight increase in its results. Apparently, this strategy has failed to achieve its objective, increasing the percentage of terminal efficiency; therefore, the curricular aspect of each of the educational programs should be analyzed, since 10 credits for social service, another 10 for professional residence, and 5 for complementary credits are considered, could be affecting the students' trajectory as they do not complete them in semester nine.

The completion indicates the culmination of the academic requirements, measured with the total credits required by the program, while graduation can and usually includes the fulfillment of other requirements, not necessarily academic, such as the integrating degree project and the dual model for obtaining the certificate.

At the end of this analysis, the data found indicates the necessity of a real application, aimed at facilitating the trajectory of the students of the educational programs of EA and EBM. Likewise, the Department of Academic Development should establish an academic advisory program to reduce educational lag, establishing the profiles and functions of the tutors of the Institutional Tutoring Program according to the academic needs of the students, reaching each Tutoring Coordinator, to enforce in the Administration Academy training and updating programs for teachers.

On the other hand, it is necessary that the complementary activities authorized by the academic committee consider all the above to favor the integral and extracurricular academic training of the students, within the regulatory times.

\section{Acknowledgments}

We appreciate the support of the Technological Institute of Campeche and to the Coordinator of Graduation Support who collaborated unconditionally in the accomplishment of this research.

\section{Conclusions y recommendations}

Planning is important for any educational institution, as it avoids the perception of isolated experiences and ensures the achievement of goals, and, without a doubt, historical records represent an opportunity to reconstruct the facts without restrictions in order to finally make the best decision. To focus the attention of academic leadership on the substantive function forming quality education, the following is recommended:

Proper planning of the promotion and admission process to reduce the rates of leaves, dropouts and transfers.

In the area of school control of the Technological Institute of Campeche, the historical records of each generation are kept, which necessarily needs to be restructured in its administration and use of information, that is, databases with individual records must be developed for the total enrollment of each educational program, incorporating the equity and gender approach, personal data, origin, etc., which can be identified through the CURP to obtain reliable and relevant information.

On the other hand, there are no records of the behavior and trends of the labor market, since there has never been a rigorous follow-up of graduates, ignoring the real needs of the different productive sectors that make up the economy of the region.

Although curricular monitoring is part of the strategic processes of quality management, there is no systematic monitoring of the reticular contents, so there is a risk of not achieving graduation profiles or handling outdated information. Although the gap between graduates has narrowed because there is a massive graduation strategy, it can be said that there is no curricular axis that allows addressing graduation from the reticle through the subjects designed for this investigation.

\section{References}

Blanco, J. y Rangel, J. (2000), La eficiencia de egreso en las instituciones de educación superior. Propuesta de análisis alternativo al indice de eficiencia terminal, en Revista de la Educación Superior, Vol. XXIX No. 114, pp. 726. 
Casarini, M. (1999). Teoría y diseño curricular. Mexico. Trillas.

Cuéllar, Ó. y Bolívar, A. (2006). ¿Cómo estimar la eficiencia terminal en la educación superior? Notas sobre su estatuto teórico. Revista de la Educación Superior, vol. XXXV (3), núm. 139, julio-septiembre, pp. 7-27. ANUIES. Mexico. Retrieved in July 2, 2019 in http://www.redalyc.org/pdf/604/60413901.pdf

DOF (2014, 07 23). Decreto que crea al Tecnológico Nacional de México. Diario Oficial de la Federación. Tomo DCCXXX, 21, pp. 4755. Retrieved in July 2, 2019 in http://dof.gob.mx/nota_to_pdf.php?fecha=22/0 7/2014\&edicion=MAT

Domínguez, D.; Sandoval, M.; Cruz, F.; y Pulido, A. (2014). Problemas relacionados con la eficiencia terminal desde la perspectiva de estudiantes universitarios. REICE. Revista Iberoamericana sobre Calidad, Eficacia y Cambio en Educación, 12 (1), 25-34. Retrieved in July 2, 2019 in http://www.redalyc.org/articulo.oa?id=5512954 1002

Furlan, A. (1998). Currículum e institución. Mexico, IMCED.

Hernández, L. (7 de Enero de 2015). Sólo 5 universitarios de cada 10 se titulan. Retrieved in November 11, 2015 from Excelsior: http://www.excelsior.com.mx/nacional/2015/01 $/ 07 / 1001285$

Hernández, R., Fernández, C. y Baptista, M. (2014). Metodología de la investigación. $6^{\mathrm{a}}$. Ed. McGRAW-HILL. Mexico, Mexico City.

Instituto Tecnológico de Campeche (2018). Programa Institucional Anual 2018. Retrieved in July 2, 2019 in http://itcampeche.edu.mx/wpcontent/uploads/2018/01/PIA-2018.pdf

OECD (2019). Higher Education in Mexico: Labour Market Relevance and Outcomes. Higher Education, OECD Publishing, Paris. Retrieved in July 2, 2019 in https://www.oecd.org/centrodemexico/medios/e ducacion_superior_en_mexico.pdf
Sánchez G. (2000). La titulación en la Universidad de Guadalajara. Trabajo presentado en el Primer Congreso Nacional Retos y Expectativas de la Universidad, Guadalajara.

SEP (2017). Sistema de indicadores de los Estados Unidos Mexicanos. INEE. Mexico.

TecNM (2014). Programa Institucional de Innovación y Desarrollo 2013-2018. Esfera creativa. Mexico.

TecNM (2015). Manual de Lineamientos Académico-Administrativos del Tecnológico Nacional de México. Planes de estudio para la formación y desarrollo de competencias profesionales. TecNM. Mexico.

Universidad Tecnocientífica del Pacífico S.C. (2015). La Universidad y sus Estrategias de Vinculación. UTP Editorial. Mexico. 